\title{
The Effectiveness of Anti-Anemia Teenage Cadre Training on Adolescent Knowledge
}

\author{
Herawati, Triana Indrayani*, Bunga Tiara Carolin \\ Faculty Of Health Science, National University, Indonesia \\ *trianaindrayani@civitas.unas.ac.id
}

\begin{abstract}
Riskesdas survey results in 2018 reveal that in Indonesia the proportion of anemia in women is $27.2 \%$ higher than in men $20.3 \%$. The proportion of anemia in the $15-24$ y.o age group is $32 \%$. In Banten Province $35 \%$ of young women suffer from anemia (Banten Provincial Health Office, 2019). In Tangerang District $63.4 \%$ of young women suffer from anemia (Tangerang District Health Office, 2017). Jayanti Public Health Center (PHC) data in 2019 reveal that from a total sample of 4 schools, 2 junior and 2 senior high schools, on average $3 \%$ of teenage girls are experiencing anemia.

To find out the effectiveness of anti-anemia teenage cadres training in Jayanti PHC in Tangerang District; and to increase the knowledge (and awareness) of teenage cadres before and after the training.

The method used in this study was the Quasy-experimental method. The research design used in this study was one group (of) pretest posttest design. The number of samples in this study, ranged in age from 16 to 19 y.o from 4 schools in Jayanti PHC, was as many as 40 people. The sampling technique used was purposive sampling technique.The research instrument consisted of a questionnaire about adolescent knowledge in adolescent anemia. Data were analyzed using paired t-test.

The results show that there were differences in knowledge scores before and after the training was given. The obtained research significance value (2-tailed) was $0,000<0.05$. There is an influence of anti-anemia teenage cadre training on adolescent knowledge. Anti-anemia teenage cadre training is expected to increase knowledge for teenagers, especially about anemia in adolescents, and for cross-sectoral,(it is expected) to support the teenage cadres in implementing their knowledge and practice in each of their school to increase anemia prevention in adolescents.
\end{abstract}

Keywords : Anemia, Training, Knowledge, Teenagers/Adolescents. 


\section{STRADA Jurnal Ilmiah Kesehatan}

DOI: $10.30994 /$ sjik.v9i2.341

ISSN: 2252-3847 (print); 2614-350X (online)

Vol.9 No.2 November 2020 Page.561-566

\section{BACKGROUND}

Anemia is a major health problem in society that is often found throughout the world, especially in developing countries like Indonesia. The world's population with anemia is around $30 \%$ or 2.20 billion people, with most of them living in the tropics. The prevalence of anemia globally is around 51\%, Suryani, Hafiani, \& Junita (2015). According to WHO (2015), if the prevalence of anemia reaches $40 \%$, (then) it is classified as a severe problem, if it reaches $10-39 \%$, it is classified as moderate and if it is less than $10 \%$ then it is classified as mild problem. WHO (2015) states that the prevalence of anemia in teenage girls is $29 \%$. The prevalence of anemia in teenage girls (10-18 y.o) reaches $41.5 \%$. WHO (2018) further reveals that the prevalence of anemia in school-age children is $25.4 \%$.

Data from the 2018 Riskesdas survey in Indonesia reveal that the proportion of anemia in women is $27.2 \%$ higher than in men $20.3 \%$. The proportion of anemia in the 15-24 y.o age group is $32 \%$. In Banten Province $35 \%$ of young women suffer from anemia (Banten Provincial Health Office, 2019). In Tangerang District $63.4 \%$ of young women suffer from anemia (Tangerang District Health Office, 2017). Jayanti PHC data in 2019 further reveals that from a total sample of 4 schools, 2 junior and 2 senior high schools, on average $3 \%$ of teenage girls are experiencing anemia.

Various efforts have been made by the government in tackling anemia, one of which is the distribution of Fe tablets to the public (Suryani et al, 2015). Anemia prevention should not only depend on the government, but it should also start from yourself.

Countermeasures to the problem carried out by Banten Province for anemia in teenagers have included simultaneous blood supplement taking for teenage girls and also - in collaboration with district/city health offices and education offices, leading/encouraging teenagers aged 15 to 18 years to take blood supplement tablets for early on stunting prevention. In Tangerang District, programs/activities such as simultaneous blood supplement taking and the formation of the Adolescent Health Care Program $(P K P R)$, the Golden Age Foster Cadres (KERAMAS) and the Anti-Anemia Teenage Cadre Training (KARTINI) are carried out in order to overcome stunting and anemia problems.

Efforts from Banten Provincial Health Office, Tangerang District Health Office and Jayanti PHC to overcome anemia problem are - conducting a movement to take blood supplemement tablets simultaneously and forming cadres such as PKPR, KERAMAS and KARTINI as to make teenagers, especially girls, be freed from anemia. Jayanti PHC itself has carried out anti-anemia teenage cadre training (KARTINI), to overcome anemia in teenagers, at school.

\section{METHODS}

The method used in this study was quasy-experimental method. The research design used in this study was one group (of) pretest posttest design. In this design, before the treatment is given - first, the samples (research subjects) are given a pretest (initial test) and at the end of the learning/training, the samples are given a posttest (final test). The population in this study were all teenage girls from 16 to 19 y.o in 4 selected schools in the area of Jayanti PHC, Jayanti, Tangerang District. The sampling technique used was purposive sampling. The number of samples in this study with age ranged from 16 to 19 y.o from 4 schools in the Jayanti PHC area, was as many as 40 people. This study was scheduled from March 2020 until the implementation of research in May 2020. The research instruments used were questionnaires, flip charts, registers for reporting the 


\section{STRADA Jurnal Ilmiah Kesehatan}

DOI: $10.30994 /$ sjik.v9i2.341

ISSN: 2252-3847 (print); 2614-350X (online)

Vol.9 No.2 November 2020 Page.561-566

implementation of anti-anemia teenage cadre training (further mentioned as - KARTINI) activities. Data were analyzed using paired t-test.

\section{RESULTS}

Univariate Analysis

Table 1 Characteristics of Respondents by Age in

Anti-Anemia Teenage Cadre Training in Jayanti PHC in 2020

\begin{tabular}{lll}
\hline AGE & total & $\%$ \\
\hline 16 & 5 & 12.5 \\
17 & 15 & 37.5 \\
18 & 17 & 42.5 \\
\hline 19 & 3 & 7.5 \\
\hline Total & 40 & 100.0 \\
\hline
\end{tabular}

Based on table 1 (it) shows that respondents aged 16 y.o are 5 people (12.5\%), respondents aged 17 y.o are 15 people (37.5\%), respondents aged 18 y.o are 17 people $(42.5 \%)$ while respondents aged 19 y.o are as many as 3 people $(7.5 \%)$.

Table 2 Adolescent Knowledge Levels in Anti-Anemia Teenage Cadre Training in Jayanti $\mathrm{PHC}$ in 2020

\begin{tabular}{lllll}
\hline & \multicolumn{3}{l}{ Intervention Group } & \\
\cline { 2 - 5 } Knowledge level & Pre-Test & & Post-Test & \\
\cline { 2 - 5 } & $\mathrm{N}$ & $\%$ & $\mathrm{~N}$ & $\%$ \\
\hline Good & 2 & 5 & 10 & 25 \\
Enough/Moderate & 18 & 45 & 28 & 70 \\
Less & 20 & 50 & 2 & 5 \\
\hline Total & 40 & 100 & 40 & 100 \\
\hline
\end{tabular}

Based on table 2 (it) shows that in the pre-test, the respondents who get good score are 2 respondents (5\%), the respondents who get enough/moderate score are 18 respondents $(45 \%)$, the respondents who get less score are 20 respondents $(50 \%)$ - while in the posttest, the respondents who get good score are 10 respondents $(25 \%)$, the respondents who got enough/moderate score are 28 respondents $(70 \%)$ and respondents who got less score are 2 respondents (5\%). 


\section{STRADA Jurnal Ilmiah Kesehatan}

DOI: $10.30994 /$ sjik.v9i2.341

ISSN: 2252-3847 (print); 2614-350X (online)

Vol.9 No.2 November 2020 Page.561-566

Bivariate Analysis

Table 3 The Effect of Anti-Anemia Teenage Cadre Training on Knowledge of Teenage Girls in in Jayanti PHC

\begin{tabular}{llllll}
\hline $\begin{array}{l}\text { Variable } \\
\text { Training }\end{array}$ & Mean & SD & SE & $P$. Value & N \\
\hline Before & 52,875 & 10,971 & 1,73471 & 0,000 & 40 \\
After & 79,235 & 14,772 & 2,33567 & & \\
\hline
\end{tabular}

Table 3 shows that the mean value of adolescent knowledge (about anemia) before the training is 52.8750 with a standard deviation of 10.971 and after the training is given, a mean value of 79.235 with a standard deviation of 14.777 is obtained - the difference between the first and second measurements is 22.360 with a standard deviation of 10.862 . The statistical test results obtain a value of 0,000 , (thus) it can be concluded that there are significant differences between adolescent knowledge before and after training.

\section{DISCUSSION}

The Age of the Respondents

The age distribution in this study is teenagers in the age range of 16 to 19 y.o., and the majority of KARTINI training participants are 17 y.o., students were selected by teachers to participate in carrying out a part in health service efforts for themselves, family, friends in particular and school students in general. There are two definitions of age, namely chronological age and biological age. For chronological age, there are young and old, while for biological age, it is determined by the condition of the brain. Teenager is teenage young adult. Teenager cannot be called as child. Adolescence is a period of human transition from children to adulthood. According to psychology, adolescence is a period of transition from the early days of children to early adulthood, which starts at the age of 10 to 12 y.o., and ends at the age of 18 to 22 y.o. (Hamidullah, 2018)

\section{Level of Knowledge Before and After KARTINI Training}

Knowledge is a theoretical and practical understanding (know-how) possessed by humans. The knowledge a person has is very important for that person's intelligence. Knowledge can be stored in books, technology, practices, and traditions. The stored knowledge can undergo transformation if used as it should. Knowledge plays an important role in the life and development of an individual, community, or organization, Basuki (2017).

According to Sulaiman (2015) the level of knowledge consists of 4 types, namely descriptive knowledge, causal knowledge, normative knowledge and essential knowledge. Descriptive knowledge is the type of knowledge that is delivered and/or explained objectively in the form of no subjectivity.

Based on this study it was found that the majority of respondents posses/have less knowledge before the intervention was given, then after being given an intervention the level of knowledge of the majority of respondents became quite good.

This study is in line with the research of Elba and Ristiani (2018) which states that there is a relationship between the frequency of training that has been followed and the knowledge of cadres about the role of the function of the 5 table system in the integrated service post or Posyandu area of the Jatinangor Public Health Center in Sumedang District. The level of knowledge of teenage cadres before and after the training have good 


\section{STRADA Jurnal Ilmiah Kesehatan}

DOI: $10.30994 /$ sjik.v9i2.341

ISSN: 2252-3847 (print); 2614-350X (online)

Vol.9 No.2 November 2020 Page.561-566

results, (as) before, the teenagers did not get enough knowledge on anemia, it could be seen at the time of the pre-test, it was found that most of the teenagers subject had limited knowledge about anemia, and with the training it is expected that they would gain knowledge and practice training about anemia, it can be seen from the results of the posttest which show an increase in knowledge in the teenagers subject after being given training.

\section{The Effect of KARTINI Cadres Training on Knowledge Level}

Anti-anemia teenage cadres are teenager role models who can be a motivator for their peers to always live healthily and apply balanced nutritional patterns in everyday life to make healthy, smart and beautiful teenagers without anemia (Nutrition Sector, District Health Office, 2019).

Based on the results study conducted in Jayanti PHC, it is found that there is an influence on KARTINI cadres training on the level of adolescent knowledge about anemia. The results of this study are in line with the research of Amerita and Ardianto (2018), to create education about anemia among teenagers and to make teenage cadres a health pioneer in their environment. The results of this study are also in line with the research of Fitrianingrum, et al (2018) in which it shows that there are significant differences in knowledge, before and after being given peer training among adolescents.

The researchers assumption about KARTINI cadre training is (that) - the significant relationship between the training of teenage cadres and the level of adolescent knowledge about anemia is due to the provision of material and counseling practice about anemia for 3 days aimed at increasing adolescent knowledge of anemia. The distribution of pre-test and post-test gives good results which is an increase (in the level of knowledge), thus the results of the effect are found to be influential/impactful in accordance with the expected results in this study.

\section{CONCLUSIONS}

Based on research in the area of Jayanti PHC, it is concluded that the majority of respondents before the intervention were found to have less knowledge, but after the intervention was given the level of knowledge of the majority of respondents became quite good. Anti-anemia teenage cadres training also has a significant influence on teenagers' knowledge about anemia. KARTINI cadre training is expected to increase knowledge for teenagers, especially about anemia in adolescents, and for cross-sectoral, (it is expected) to support the teenage cadres in implementing their knowledge and practice in each of their school to increase anemia prevention in adolescents.

\section{REFERENCES}

Anwar Hidayat. (2017). Penjelasan Teknik Purposive Sampling Lengkap Detail. diunduh pada 25 April 2020 dari https://www.statistikian.com/2017/06/penjelasan-teknikpurposive-sampling.html

Basuki, A., Astuti D, SKM., M.Kes dan Darnoto S, SKM., MPH. (2017). Hubungan Tingkat Pengetahuan Dengan Perilaku Hidup Bersih Dan Sehat Siswa SD Negeri IV Baturetno Kecamatan Baturetno Kabupaten Wonogiri. [skripsi]. Surakarta (ID): Universitas Muhammadiyah.

Dannayanti, Y., Yuniar, L., \& Mery, R. (2011). Peran Teman Sebaya terhadap Perilaku Seksual Pranikah Siswa SLTA Kota Bukit Tinggi. Jurnal Kesehatan Masyarakat, 6(1), 24-27. 


\section{STRADA Jurnal Ilmiah Kesehatan}

DOI: $10.30994 /$ sjik.v9i2.341

Dinkes Kabupaten Tangerang. (2017). Profil Kesehatan Kabupaten Tangerang. Diunduh pada 20 April2020 dari http://dinkes.tangerangkab.go.id/wpcontent/files/Profil_Kesehatan_Kabupaten_Tangerang_2017.pdf

Dinkes Provinsi Banten. (2019). Profil Kesehatan Provinsi Banten. Diunduh pada 20 April 2020 dari https://dinkes.bantenprov.go.id/read/profil-kesehatan-provinsibant/180/Profil-Kesehatan-Provinsi-Banten-Tahun-2019.html

Dwi, N. W. (2019). Buku Anemia Zat Besi. Sleman: Deepublish.

Hafiani, R., Junita, R., Suryani, D. (2015). Analisis Pola Makan dan Anemia Gizi Besi pada Remaja Putri Kota Bungkulu. Jurnal Kesehatan Masyarakat Andalas, 10 (1), 11-18.

Hesni, E. (2017). Konseling Gizi Sebagai Bentuk Pendampingan Remaja Putri Anemia oleh Kader Remaja Anti Anemia (KADERAMIA). [skripsi]. Yogyakarta (ID): Politeknik Kesehatan Kemenkes Yogyakarta.

Lembaga Demografi FEB UI. (2017). Ringkasan Studi: Prioritaskan Kesehatan Reproduksi Remaja Untuk Menikmati Bonus Demografi. diunduh pada 24 April 2020 dari www.ldfebui.org

Masrizal. (2017). Anemia Defisiensi Besi. Jurnal Kesehatan Masyarakat, II (1).

Mutiah., Sri, A. M. (2019). Pengaruh Dukungan Sosial Teman Sebaya terhadap Prestasi Belajar Siswa Kelas VII-1 SMP Negeri 5 Seruway Aceh Tamiang Tahun Ajaran 2018/2019. [skripsi]. Sumatera Utara (ID): Universitas Islam Negeri.

Meilan, S., Maryanah., dan Follona, W. (2018). Buku Kesehatan Reproduksi remaja: Implementasi PKPR dalam Teman Sebaya. Malang: Mineka Media.

Notoatmodjo, S. (2010). Ilmu Perilaku Kesehatan. Jakarta: Rineka Cipta. (2012). Metodologi Penelitian Kesehatan. Jakarta: Rineka Cipta.

Nuraeni, R., Puspa, S., Neneng, M., Sri, A., \& Lina, R. (2019). Peningkatan Kadar Hemoglobin melalui Pemeriksaan dan Pemberian Tablet Fe Terhadap Remaja yang Mengalami Anemia Melalui "Gerakan Jumat Pintar". Jurnal Pengabdian kepada Masyarakat, 5(2), $200-221$.

Ommakplus. (2015). Definisi atau Pengertian Pelatihan. Diunduh pada 25 April 2020 dari http://www.definisi-pengertian.com/2015/06/definisi-atau-pengertianpelatihan.html

Rinieng, Is., Sri, S., Mamik. (2016). Hubungan Status Gizi dengan Kejadian Anemia pada Santriawati di Pondok Pesantren Darul Ulum Peterongan Jombang. Jurnal Keperawatan Muhammadiyah, 1, 7-15.

Sugiyono. (2012). Metode Penelitian Kuantitatif Kualitatif dan R\&D. Bandung: Alfabeta.

Sya'bani, I. R. N., \& Sumarni, S. (2016). Hubungan Status Gizi Dengan Kejadian Anemia Pada Santriwati Di Pondok Pesantren Darul Ulum Peterongan Jombang, Jurnal Keperawatan Muhammadiyah, 1 (2).

World Health Organization. (2015). Haemoglobin concentrations for the diagnosis of anaemia and assessment of severity. Diunduh pada tanggal 24 April 2020 dari https://www.who.int/vmnis/indicators/haemoglobin/en/ 